\title{
Politeness Strategies On Ordering Speech Act
}

\author{
Agustina Aloojaha \\ Program Studi Pendidikan Bahasa Inggris, Fakultas Keguruan dan Ilmu \\ Pendidikan, Universitas Tribuana Kalabahi, Alor, Nusa Tenggara Timur \\ agustinanipualoojaha@gmail.com
}

\begin{abstract}
This research is a translation study on politeness strategies in ordering speech act of novel Christ the Lord out of Egypt and its translation in Indonesian, Kristus Tuhan Meninggalkan Mesir. The purpose of this research is to describe how politeness strategies exist in ordering speech and how politeness strategies impacted the translation qualites. This research used qualitative descriptive method. The data source of the research is the document in the form of the novels namely original novel and translation novel. The data are focused on the sentences that accommodate politeness strategy in ordering speech act. Politeness strategies are known through translation techniques that are used in the novel translation. By analyzing data, it showed that the politeness strategies used in ordering speech act are bald on record, positive politeness, negative politeness, and off record. Based on the data, translation qualities of ordering speech sentences in the novel translation have shifted because of the use of politeness strategies. Furthermore bald on record is more shifted than other because it is shifting into positive politeness. So it can be concluded that the politeness strategies have changed the meaning of ordering speech on source language in English as asking speech on target language in Indonesian.
\end{abstract}

Keywords: Translation; politeness strategies; ordering speech.

\section{Intisari}

Penelitian ini merupakan kajian penerjemahan pada strategi kesantunan dalam tindak tutur menyuruh pada novel Christ the Lord out of Egypt dan novel terjemahan Kristus Tuhan Meninggalkan Mesir. Tujuan dari penelitian ini adalah untuk mendeskripsikan strategi kesantunan yang digunakan penerjemah dalam tuturan menyuruh dan bagaimana strategi kesantunan tersebut mempengaruhi kualitas penerjemahan. Penelitian ini menggunakan metode deskriptif kualitatif. Sumber data penelitian adalah dokumen berupa novel yaitu novel orisinal dan novel terjemahan. Data difokuskan pada kalimat-kalimat yang mengakomodasi strategi kesantunan dalam menyusun tindak tutur menyuruh. Strategi kesantunan diketahui melalui teknik penerjemahan yang digunakan dalam menerjemahkan novel. Hasil analisis data menunjukkan bahwa strategi kesantunan yang digunakan dalam menyusun tuturan menyuruh adalah bald on record (tuturan langsung), positive politeness (kesantunan positif), negative politeness (kesantunan negatif), dan off record (tuturan tak langsung). Berdasarkan data strategi kesantunan, tuturan menyuruh yang banyak berubah karena strategi kesantunan adalah tuturan menyuruh langsung (bald on record) berubah menjadi tuturan menyuruh positif atau sopan dalam novel terjemahan.

Kata kunci: Penerjemahan; strategi kesantunan; tuturan menyuruh. 


\section{Introduction}

In digital era, novel is still an interesting reading for all people who can read. That is because every story still has a magic that is challenging to have it. And it also attracts the readers as if the story is their own story. That is why, it influenced them to own the novel.

This becomes even more interesting when the novel is in a language that the reader does not understand. It means that the novel must be translated into the language of the readers so they can understand. This encourages publishers to do their best to find translators to translate novels that are considered the best-sellers.

Based on the above statements, of course a translator is needed to translate. And the point is that the translator needs to get serious attention, i.e. a translator must really person who is competence as a translator. Because the case of translating is not only has the ability to speak and write with source language but must be understood the rules or linguistics features that exist in target language. Furthermore, culture is also major factor in translating. For this case, there are European culture and Indonesian culture. So to understand these cultures, it can helps translators to comprehend the whole context of story.

Here when the context of the story in source language (English) is translated into the target language (Indonesian), the authenticity of the story in the original novel is must be still maintained and up to the readers of target language without diminishing the meaning of the original story.

In this study the researcher examined the strategy of politeness on ordering speech act in the novel Christ the Lord out of Egypt and its translation Kristus Tuhan Meninggalkan Mesir to know the quality of translation weather it still defended the real meaning of source language or it has been reduced.

Talking about the quality of translation, some translation experts have expressed their opinions as follows:

Translation is interpreted as a diversion of meaning as stated by Nida and Taber (1969: 12), translation is to re-create meaning in the natural language of possible target so that its meaning is close to the message in the source language, taking into account two things, first in meaning and second in style. 
From these statements we know that the most important translation problem is the understanding of meaning.

Another expert, Newmark (1988) provides the definition of translation as an attempt to restate the meaning of a text in another language as the original author desires.

Further Catford (1969: 20) states that translation is the replacement of the textual material of a language, source language (SL) by textual material equivalent in other languages, target language (TL). The word match is clearly the essence of a translation. In other words, translation is searching for the correspondence of words in the target language.

From some of the above meanings, it can be concluded that translation is the process of transferring meaning from the source language (SL) to the target language (TL) where the meaning in the target language should be as accurate as possible and the grammar should be as natural as possible, so that when read, the reader is unaware that they read the translation results.

In translating, it is not enough for a translator to have abilities on grammar of the language to be translated, but must know and understand well the linguistic culture of the source language. Not only the source language that the translator must pay attention but also the target language must be carefully considered about its culture. For example, the target language is Indonesian. Then it can be said that the constraints of a translator is the language and culture itself. Thus, of course, a translator is bilingual or multilingual and bicultural or multicultural (Emzir, 2015).

Furthermore, the linguistic case which concentrates this research is pragmatics. Talking about pragmatics, in telling each story plot is inseparable from the context of speech spoken by every character or cast. There is a speech that utterance of speech is directly, but not infrequently in some speech hinted at other intentions and the responded sometimes given by the speakers who cursory not answer the previous speech. And such speech forces the reader to dig up meaning to understand what is meant in the speech.

In the communication model, which describes the information flow from speakers to hearers, there is a section called encoding. This encoding lies between the speaker's brain (i.e., the source of information) and the speaker's speech utensils, 
which serve as the transmitter of messages or information derived from the source. It basically refers to the selection of the code used in certain language. The consideration of choosing a coding is inseparable from the sociolinguistic "argumentative," who speaks to whom, where, when, about what, for what and how. In order to make sense of what is said in an interaction, we have to look at various factors which relate to social distance and closeness. Some of these factors are established prior to an interaction and hence are largely external factors. They typically involve the relative status of participants, based on social values ties to such things as age and power. For example, speakers who see themselves as lower status in English-speaking contexts tend to mark social distance between themselves and higher status speakers by using address forms that include and a last name not the first name.

The consideration of who speaks to whom it basically refers to the relationship between the participants of the communication, i.e. whether the one speaker is more senior (in the sense of power, status or rank is higher and so on) than another speakers, and whether their relationship is closeness or not (Kuncara, Nababan, and Samiati, 2013).

However, there are other factors, such as amount of imposition or degree of friendliness, which are often negotiated during an interaction. These are internal to the interaction and can result in the initial social distance changing and being marked as less, or more, during its course. This may result, for example, in participants moving from a title-plus-last name to a first name basis within the talk. These internal factors are typically more relevant to participants whose social relationship are actually in the process of being worked out within the interaction. Both types of factors, external and internal, have an influence not only what we say, but also on how we are interpreted. In many cases, the interpretation goes beyond what we might have intended to convey and include evaluations such as 'rude' and 'inconsiderate', or 'considerate' and 'thoughtful'. Recognizing the impact of such evaluations makes it very clear that more is being communicated than is said. The investigation of that impact is normally carried out in terms of politeness (Yule, $1996 ; 60)$ 
As the science of pragmatics, the consideration of choosing the codes do not enough at the sociolinguistics considerations are mentioned, but needs to be expanded to include the following:

Whether the speech that the one speaker expressed has the potential to threaten the another speaker's face or not (face saving act);

How is the relative quality of speech efforts to be expressed within the culture; Whether the one speaker has a pragmatic compensation to reduce or mitigate the effects of face-threatening act (FTA) so that the speaker's speaking is a facesaving act (FSA), which can be verified politeness (Purwaningrum, 2017).

This study attempts to define the pragmatics and translation cases, i.e. the politeness strategy on ordering speech in source language that changed the meaning on target language. So it is shifting meaning. It also impacted the quality of translation to be asked. That is how the one speaker expresses the utterance to another speaker, and how the translator translates it from the source language into the target language.

\section{Research Methods}

The research is an exploratory research. This type is defined as a research used to investigate a problem which is not clearly defined. There is two ways in which research can be conducted namely primary and secondary. In this case, the researcher used secondary research where is gathering information from previously published primary research. In such the researcher gathers the information from sources as novels. The research is also a qualitative descriptive research with case study stuck and ethnographic. With regard to the field of translation, this research is a product-oriented translation research. The source of data in this study is Christ the Lord of Egypt and its translation "Kristus Tuhan Meninggalkan Mesir." While the data are sentences that accommodate ordering speech in the source language and the target language and the quality of the translation. Data conducted through document analysis. To assess the quality of the translation, the researcher involves three informants to assess the quality of the translation. 


\section{Results and Discussion}

\section{Types of Politeness Strategy on Ordering Speech}

The analysis of politeness strategy shows that there are four types of politeness strategies that are used to translate namely bald on record (90 data), off record (12 data), positive politeness (12 data), and negative politeness (11 data). Bald on record being the majority is possible with the theme of Christ the Lord out of Egypt novel is about small Jesus adventure with his family, where Jesus began to find out his identity in the Temple in Jerusalem but the condition of the city was not conducive, so they used direct to converse. Yet it becomes interesting again, though using direct speech, in translation novels, the translator adds some features of polite markers such as the word "coba", and the particle "lah" so that impact on the quality of the translation.

Likewise with reducing the word in the source language into the target language, this actually intends to compress the information in the target language but the result is fatal because the value of politeness in the source language is not maintained in the target language. This will be discussed in the discussion. Meanwhile, the strategy of "do not do the FTA" politeness is not found in the data because it does not involve speech language so it cannot be classified in the object of study in this study. For more details, will be presented in the table as follows:

Table 1. 1. Types of Politeness Strategies on Ordering Speech in Novel Christ the Lord out of Egypt and its translation.

\begin{tabular}{|c|c|c|c|}
\hline No & Findings & $\begin{array}{c}\text { Types of politeness } \\
\text { strategy in source language } \\
\text { (SL) and target language (TL) }\end{array}$ & Subtotal \\
\hline \multirow[t]{5}{*}{1} & \multirow{4}{*}{$\begin{array}{l}\text { Politeness } \\
\text { strategies did not } \\
\text { shift }\end{array}$} & Bald on record & 54 \\
\hline & & Off record & 12 \\
\hline & & $\begin{array}{l}\text { On record positive } \\
\text { politeness }\end{array}$ & 10 \\
\hline & & $\begin{array}{l}\text { On record negative } \\
\text { politeness }\end{array}$ & 9 \\
\hline & \multicolumn{2}{|l|}{ Subtotal } & 85 \\
\hline \multirow[t]{5}{*}{2} & \multirow{4}{*}{$\begin{array}{c}\text { Politeness } \\
\text { Strategies shifted }\end{array}$} & Bald on record & 36 \\
\hline & & Off record & - \\
\hline & & $\begin{array}{l}\text { On record positive } \\
\text { politeness }\end{array}$ & 2 \\
\hline & & On record negative politeness & 2 \\
\hline & \multicolumn{2}{|l|}{ Subtotal } & 41 \\
\hline \multicolumn{3}{|r|}{ Total } & 126 \\
\hline
\end{tabular}


The data show 126 utterances those accommodate ordering speech acts and using four types of politeness strategies from Brown and Levinson.

\section{Findings on Translation Techniques of Ordering Speech Act}

Table 2.1 Types of Translation Techniques and Its Frequency

\begin{tabular}{|c|c|c|c|}
\hline Number & Translation Techniques & Sum & Percentage \\
\hline 1 & Established Equivalent & 400 & $60,42 \%$ \\
\hline 2 & Variation & 88 & $13,30 \%$ \\
\hline 3 & Implication & 36 & $5,44 \%$ \\
\hline 4 & Explicit & 36 & $5,44 \%$ \\
\hline 5 & Addition & 38 & $5,74 \%$ \\
\hline 6 & Modulation & 20 & $3,02 \%$ \\
\hline 7 & Adaptation & 16 & $2,42 \%$ \\
\hline 8 & Pure Borrowing & 9 & $1,36 \%$ \\
\hline 9 & Generalization & 4 & $0,60 \%$ \\
\hline 10 & Paraphrase & 4 & $0,60 \%$ \\
\hline 11 & Transposition & 3 & $0,45 \%$ \\
\hline 12 & Reduction & 3 & $0,45 \%$ \\
\hline 13 & Particularization & 2 & $0,30 \%$ \\
\hline 14 & Discursive Creation & 2 & $0,30 \%$ \\
\hline 15 & Naturalized Borrowing & 1 & $0,15 \%$ \\
\hline & Total & $\mathbf{6 6 2}$ & $\mathbf{1 0 0 \%}$ \\
\hline
\end{tabular}

Based on the table, this research found 15 types of translation techniques which used to translate 125 utterances those accommodate ordering speech act. These translation techniques are according to Molina and Albir (2002). Furthermore read from frequencies translation techniques those use ordering speech act still maintain the quality of translation namely accuracy, readability, acceptance.

\section{Quality of Translation}

The quality of the translation covers on 3 aspects, namely aspects of accuracy, acceptance, and readability. In assessing the quality of translation, the researcher used translation rating scale that is formulated by Nababan (2012).

After all data relating to accuracy, acceptability, and readability are collected, the values given by each rater are in following formula:

Average $=\underline{(\mathrm{R} 1+\mathrm{R} 2+\mathrm{R} 3)}$ 
Based on these calculations the average of accuracy is grouped into three categories, such as:

a) Accurate translation with an average of $2.66-3.00$

b) Translation is less accurate with an average of $1.34-2.65$

c) Not accurate translation with an average value of $1.00-1.33$

Likewise the way to calculate the value of acceptance and readability is the same as how to calculate the value of accuracy.

\section{Discussion}

1. Types of politeness strategies in novel Christ the Lord out of Egypt and its translation in Indonesian

There are four types of politeness strategies according to Brown and Levinson:

\section{a) Bald on Record}

Bald on record is a speech strategy that directly without chit chat.

\section{1) Bald on record did not shift}

Based on the findings, there are 90 utterances which are spoken directly. Those consisting of 54 data did not shift and 36 data shifted. Next, the researcher presents an example of bald on record did not shift and an example shifted.

Bald on record did not shift is showed by these examples below:

$>$ Data number: C2/SL12/TL29

SL: "Think of the night when the the man from the East came"

TL: "Ingat malam ketika orang-orang majus dari Timur datang"

Situation context:

In this conversation Mary told Joseph, Cleopas and others to recall the events of the night of Jesus' birth, how do Magi from the East came with gold, incense and myrrh. This sentence is clearly seen Maria told them politely and without ado. Meanwhile in translation novel, it also did not shift because translator uses established equivalent, modulation and generalization techniques those in translation techniques are techniques which raise up the quality of translation from 3 aspects of quality, namely accuracy, acceptability, and readability.

\section{2) Bald on record shifted}

\section{Data Number: C3/SL18/TL44}

SL: "Go there, and sit with your mother and the children," he said.

TL: "pergilah ke sana, dan duduklah dengan ibumu dan anak-anak lain, ” katanya. 
Situation context:

This conversation took place on the ship while they were on a voyage with other passengers from Egypt to Jerusalem. In Indonesian translation, translator uses addition technique to add politeness markers, that is, particle lah. This is certainly good because Indonesian culture tends to be polite in delivering any speech so that can improve the quality of acceptance and readability in the target language. But this cannot be accepted in terms of accuracy because this story does not belong to Indonesians but to Europeans who tend to deliver direct speech without further ado. So this speech is categorized as shifting speech that is, shifting from bald on record to positive politeness.

\section{b) Off Record}

Bald off record is a politeness strategy with vague or non-transparent speech. In this research, the researcher found that there were 12 speeches those accommodate the bald off record politeness strategy and all the data did not shift. Next the researcher presents 2 data politeness strategies on bald off record those do not shift.

\section{1) Off Record did not shift}

$>$ Data number: C1/SL9/TL21

SL: "Joseph, it's not wise to say such a thing," the Teacher said.

TL: "Yusuf, tidak bijaksana berbicara begitu," kata sang Guru.

Context situation:

This speech was delivered by Jesus's teacher to Joseph. In their conversation, Joseph spontaneously said the reason for bringing his family home was because King Herod would die soon. That statement was considered rude and inappropriate by teacher because Herod was a King of a large nation and still very healthy. So the speech is conventionally a declarative sentence containing prohibitions and advice.

Meanwhile, rated from the results of the translation, the speech did not shift because the source language is translated using adaptation technique, implication technique and established equivalent technique. In addition it has fulfilled the good standardized of translation. And based on the analysed the data, there is not found bald off record shifted. 


\section{c) Positive Politeness}

There are 12 ordering speeches those used positive politeness consisting of 10 speeches did not shift, and 2 speeches shifted, as the examples below:

\section{1) Positive Politeness did not shift}

\section{Data Number: C2/SL13/TL31}

SL: "I don't want you to ask, do you understand?"

TL: "Aku tak ingin kau bertanya, apa kau mengerti?"

Context situation:

This speech was delivered by Joseph to Jesus. Little Jesus asked Joseph about the new King who will be replaced Herod. And it made Joseph nervous that he answered Jesus' questions with statement "I don't want you to ask, do you understand?" Can be categorized as a positive politeness strategy, because Joseph was not angry and ordered Jesus directly to be quiet but instead he used an interrogative sentence to tell Jesus to stop asking what he could not yet understand. Meanwhile, the politeness strategy used did not shift. Furthermore, the results of the translation do not shift because the translator uses the right translation technique to translate namely variation technique, established equivalent technique, and explicit technique.

\section{2) Positive politeness shifted}

\section{$>$ Data number: C1/SL5/TL12}

SL: "Just make him come alive, Jesus, the way you made the birds come alive!" TL: "Bikin dia hidup, Yesus, seperti saat kau menghidupkan burung-burung itu" Situation context:

This conversation took place between Jesus and his cousin, Salome, when Jesus was accused of having killed Eleazar. And Salome in his innocence told Jesus to revive Eleazar because he had seen Jesus make birds from clay and immediately they lived in Jesus' hands and flew into the air. Related with shifting politeness strategy, the researcher categorized that the positive politeness strategy is shifted to bald on record because in the original text the author uses the word "just" at the beginning of the sentence. This shows that Salome respected Jesus as his brother and someone different from them. So the word "just" greatly influences the meaning 
of politeness. But in the target language the word "just" is not translated by translators.

In translation terms, the translator tries to compress information from the source language to the target language by reducing words that the translator thinks are not important. But in this case reduction actually has fatal consequences because the politeness value of a speech has been ignored. How to translate like this is actually good because it can improve the quality of acceptance and readability of a translation but it causes problems in the accuracy of the translation because the polite and innocent impression as the character of Salome given to Jesus is not maintained in the target language that describes as if Salome is bigger than Jesus so he can rule it.

\section{d) Negative Politeness}

There are 11 speeches which contain negative politeness. Consisting of 9 negative politeness did not shift and 2 negative politeness shifted. It is represented on sentences below:

\section{1) Negative politeness did not shif}

Data number: C1/SL7/TL16

SL: Listen to your own words!"

\section{TL: Betapa tak pantasnya kata-kata kalian!"}

Context situation:

When Joseph was talking with Jesus' teacher about his planned to return from Egypt to Jerusalem, the teacher was doubtful because Herod was very cruel at the time. Therefore, Joseph assured the Teacher that they would be fine, by giving a statement that Herod would die in the near future. Hearing that, the Teacher immediately rebuked Joseph. In context, this speech was used by the teacher not only to reprimand Joseph for speaking ill-mannered about King Herod but to the meaning of order speech to Joseph to be quiet.

Researcher categorized this speech as negative politeness because it contains elements of criticizing Joseph who has spoken sensitive and inappropriate things about a very powerful King like King Herod.

Furthermore, in translation, politeness strategy does not shift because it uses explicit translation techniques that make speech in the target language more 
explicitly criticizing Yusuf so that it supports negative strategies of politeness not shifting and the quality of the translation becomes high.

\section{2) Negative politeness shifted}

$>$ Data number: C8/SL44/TL106

SL: "If you must speak against his mother, then speak."

TL: "Kalau kau mau menentang keinginan ibunya, maka bicaralah."

Context situation:

This statement was delivered by Joseph to Cleopas. Cleopas urged Joseph to talk to Elisabeth to cancel his plan to give Johannes (Elisabeth's son) to the Essenes. However, Joseph was well acquainted with the character of Elisabeth, Zacharias' widow, so he would not say anything to persuade her because he knew he would not succeed in persuading Elisabeth. So Joseph stated the statement "If you must speak against his mother, then speak."

In terms of translation, this utterance shifts because of the use of addition technique for translating such as adding particle 'lah' in target language. It means the sentence shifted from negative politeness in source language to positive politeness in target language.

\section{The Influences of Translation Techniques toward Politeness Strategies in Ordering Speech Act}

\section{a. Translation technique that influence politeness strategy did not shift}

By analyzing of translation techniques and their influences on speech politeness strategies showed the same tendency in source language and target language. Especially the established equivalent technique has a big influence on politeness strategies in order speech between SL and TL because it deemed more appropriate to translate those utterances.

\section{b. Translation Technique that Influence Politeness Strategy Shifted}

Translation techniques those cause the shift of meaning are Addition technique, reduction technique, and creation discursive technique. Addition technique is done by adding a marker of positive politeness so the order speech in bald on record changed into order speech in positive politeness. And reduction technique shifted from positive politeness strategy to bald on record and negative politeness. In the 
other hand with discursive creation technique, the technique causes a shift in the bald on record strategy to become positive politeness.

\section{The Influence of Translation Technique Toward Translation Quality}

The techniques which influenced a good translation are variation, implicit, explicit, adaptation, modulation, pure borrowing, generalization, particularization, transposition, paraphrase, and naturalized borrowing. Whereas the techniques which influenced less good translation are addition, reduction, discursive creation.

\section{Conclusion}

This article discusses the translation on politeness strategies those are used in ordering speech act of novel translation. To know politeness strategy, it is showed on translation techniques those was using by translator. It has been impact on translation qualities in the accuracy, acceptance and readability. So it can be concluded that the tendency of the impact of the use of techniques on quality in the target language is very good but cannot be said to be perfect because some translation techniques that affect the shifting politeness strategy and the quality of speech prompts, that is, addition, reduction and discursive creation techniques. In the politeness of speech utterance strategy, the use of translation techniques results in translations that are well accepted and of high readability. Thus, addition techniques tend to have a positive impact on the target language, but have a negative effect on the source language, because the translator has added other words into the target language that are not in the source language, as well as the problem of reducing words that exist in the source language into the language the target is very influential on the meaning of the original message.

Thus, the benefits of this research are expected to provide a little information and guidance in conducting translational activities, namely by considering linguistics features, especially in the pragmatics field because translation cannot be separated from the context of speech. 


\section{References}

Brown, P and Levinson S. (1987). Politeness: Some Universals in Language Usage. Cambridge: Cambridge University Press.

Catford, J. C. 1969. A Lingusitics Theory of Translation. London: Oxford University Press

Emzir. 2015. Teori dan Pengajaran Penerjemahan. Jakarta: Rajawali Pers

Kuncara, S.D., Nababan, M.R., Samiati, S. (2013). Analisis Terjemahan Tindak Tutur Direktif Pada Novel [Analisis in the Translation of Direct Speech Act Used in the Novel Godfather and Its Translated Version in Bahasa Indonesia]. Translating Journal: translation and Linguistics, 1 (1), 1-20.

Larson, M. L. 1984. Meaning Based Translation. Lantham, Maryland: UPA

Larson, M. L. 1989. Penerjemahan Berdasarkan Makna: Pedoman untuk Pemadanan antar Bahasa, terjemahan Kencanawati Taniran, Jakarta: Arcan.

Larson, Mildred L. 1998. Meaning Based Translation: A Guide To Cross Language Equivalence. Lanham dan New York: University Press of America. INC

Molina, Lucia \& Albir, Hutardo. 2002. Translation tecniques Revisited: A Dynamic and Functionalist

Nababan, M. R. 2003. Teori Menerjemahkan Bahasa Inggris. Yogyakarta: Pustaka Pelajar.

Nababan, M. R. 2012. Pengembangan Model Kualitas Terjemahan. Kajian Linguistik dan Sastra, 24 (1), 39-57. Retrieved from http://publikasiilmiah.ums.ac.id/bitstream/handle/11617/2220/4. MANGATUR NABABAN. Pdf; sequence $=1$

Newmark, P. 1988. A Textbook of Translation. New York: Prentice-Hall International

Nida E. A \& Taber, Charles R. 1969. The Theory and Practice of Translation. Leiden: E J Brill

Purwaningrum, P.W. (2017). Strategi Bertutur Dalam Tuturan Memerintah Pada Situasi Komedi Tukang Ojek Pengkolan (Eps. 9), IX (2), 81-88.

Rahardi, Kunjana. 2005. Pragmatik. Kesantunan Imperatif Bahasa Indonesia. Penerbit Erlangga. Jakarta

Spradley, James P. (1980). Participant Observasion. Holt Rinehart, and Winsto.

www.kelasindonesia.com/2015/07/penjelasan-partikel-kah-lah-tah-pun-dibahasa-indonesia.html? $m=1$

Yule, George. 1996. Pragmatics. Oxford University Press. Walton Street, Oxford ox2 6DP.

Yule, George. 1996. Pragmatik. Penerbit Pustaka Pelajar. Yogyakarta.

https://en.wikipedia.org/wiki/Novel

https://www.obritannica.cm/art/novel 